\title{
Impacts and Benefits of Convention and Meeting Industry on Local Destination
}

\author{
Song Chengcheng \\ Department of Business Administration \\ School of Management, Zhejiang University \\ Hangzhou, Zhejiang, P.R.China \\ fendou1374@126.com
}

\author{
Qi Shan \\ School of Hotel Tourism Management \\ Hong Kong Polytechnic University \\ Hong Kong, Hong Kong \\ 12144452g@polyu.edu.hk
}

\begin{abstract}
Despite increasingly focus has been on Convention and Meeting industry on a world wide range, as it would bring both economic and non-economic benefits to local destinations, it still require more attention to the difference between convention and meeting. Early researchers indicate that a wide range of accessibility, facility, travel-ability are influencing peoples' decision making, both participants and PCOs. Meanwhile, convention and meeting industry also have some side effects which would dissatisfy its local residents, even it could generate economic benefits to the whole society.
\end{abstract}

Keywords-Convention Industry; Meeting Industry; Tourism Managmeent; Convention and Meeting Managemnet; Destination Evaluation.

\section{INTRODUCTION}

Convention and meeting industry has experienced a significant development over the past several decades, even though the external economic environment is unstable all around the world (MPI, 2012). It has become a value-creating segment for most of countries, and a risingup industry especially in Asia area. As we can see from the ICCA or UIA report that Singapore and Seoul also rose up to the site decision makers' top choices for the last decade (UIA, 2011; ICCA, 2011). Having noticed about the great economic and social impact that the convention and meeting industry has brought with, both regional and subregional governments are all willing to develop it.

Moreover, the convention and meeting industry has great, but not "unlimited" growth potential. It can generate not only "substantial return of investment", but also intangible and sustainable benefits for the host location (Lew, A. A. \& Chang, T. C., 1999). And, there are also negative impacts aroused in the industry to destinations. Although the convention and meeting industry have a considerable economic and society effect, not all the destinations are suitable to "actively promote conventions and meetings". There are several criteria for site decision makers to measure a destination's possibility of becoming a host site.

\section{TERMILOGY}

\section{A. Convention}

The largest market of MICE industry around the world is occupied by the association and convention business (Dwyer, 2002). The conventions are driven by the association, in which people have same interest or share same objectives. Based on the different objectives, conventions can be classified into various forms, such as training and development programs, networking functions and seminars.

Associations need to get invitation from the local counterparts, and invite people to participate (Weber, K., $\&$ Chon, K. S., 2002). People have the right to choose to go or which one to go. And participants have to pay for their own cost. Therefore, to attract more delegates to join in the convention held by the association, the committees usually promote it through multi-media methods, like the website, social media, and online video. According to Weber and Chon (2002), conventions mostly are large in groups' size (more than 100) and longer in duration (three to five days in general). Because of the large size of convention, it usually needs less than five years as preparation. And also, to benefit each of the delegates from around the world, the convention destination most likely rotates around the world at spring or autumn. As for the venue and facilities, breakout rooms, plenary sessions, convention centers and universities are needed.

\section{B. $\quad$ Meeting}

In contrast of the convention, the meeting usually was defined as the corporate meetings which are driven by the needs of individual business. Corporate meetings are commonly composed of board or shareholders' meeting, training seminars, meetings with business partners or clients and strategic planning retreat.

Researchers have put much effort on study the unique characteristics of corporate meetings (Lawson, 2000; Johnson et.al., 1999). The corporate meetings have several features in different aspects. First, the corporate meetings are held as needs are aroused annually, such as training, shareholders meetings (Lawson, 2000). Thus, the lead-time of corporate meetings is much shorter than conventions. It usually takes the PCO one to six months to prepare for it. Secondly, the final say of decision is held in the headquarters, even though the PCO may influence their preference of choice (Sangpikul A. and Kim S. S., 2009). The company would cover the cost of meeting for each attendee. This, in turn, requires the employees must participate in the meeting. Also, the delegates would be accommodated in 3 or 4 star hotels with qualified or standard meeting facilities. Additionally, the corporate meetings are usually small in the size of delegates' number (less than 100) and short in duration (Weber and Chon, 2002). For ordinary meetings, it only last for 1-2 days. For the meetings sever as training, the duration will be 3-5 days in general. 


\section{GROWTH POTENTIAL OF CONVENTION AND MEETING INDUSTRY}

Convention and meeting industrialization can be traced back to the late nineteenth and early twentieth century in United States and Western Europe. Before that, people gathered together for a common interest at a selected location to have a face-to-face communication. However, the need for face-to-face meetings is declining since last decade. The research conducted for the Hilton Hotels (Richard. D, 2009) showed that most of participates agreed that cost and expenses have resulted in fewer meetings and more phone and video conferencing. Christine and Mary (2010) indicate that the formation of group meetings and events had become remarkably complex. They can be completely face-to-face, completely virtual, or a hybrid of these two. Thus, with the rapid changes of technology and people's behavior, new terminology will come out and replace the convention and tourism industry. There will be new modes or new concepts of business that will better serve people's needs for establishing relationship between association members and access to business opportunities.

Meanwhile, the convention and meeting industry indeed has great growth potential nowadays. From the Figure 1, we can see that the European and American markets are mature, whereas the Asia market is in booming stage. Since 2009, Singapore has become the Top1 on the list of cities for international conventions. Seoul and Tokyo were ranked top 5 and top 7 respectively at the year of 2011. Meanwhile, the numbers of international meetings held in Mainland China increased continuously. So it is believed that China's MICE industry has great potential in the future. Helms Briscoe (2011) predicted that the MICE sector is $\$ 150$ billion market with annual growth of $20 \%$. The $5^{\text {th }}$ China and Asia Meetings report also demonstrated that suppliers from Beijing, Shanghai, Hong Kong and Taiwan are most likely to attract new business in the future, closely followed by other Asia cities.

\begin{tabular}{|c|c|c|c|c|c|c|c|c|c|}
\hline 1954 & 1968 & 1974 & 1988 & 1992 & 1999 & 2002 & 2005 & 2009 & 2011, \\
\hline Paris & Paris & Paris & Paris & Paris & Paris & Paris & Paris & Singapore & Singapore, \\
\hline Geneva & Geneva & London & London & London & Brussels & Broussels. & Vienna & Brussels & Brussels, \\
\hline London & London & Geneva & Madrid & Brussels & Vienna & London & Brussels & Paris & Paris, \\
\hline Rome & Brussels & Brussels & Brussels & Vienna & London & Vienna & Singapore & Vienna & Vienna, \\
\hline Brussels & Strasbourg & Rome & Geneva & Madrid & Singapore & Singapore. & Barcelona & Geneva & Seoul, \\
\hline New York & Vienna & New York & West Berlin & Geneva & Berlin & Copenhagen & Geneva & Berlin & Budapest, \\
\hline Vienna & Rome & Vienna & Rome & Amsterdam & Amsterdam & Barcelona & New York & Prague & Tokyo \\
\hline Amsterdam & New York & Washington & Sydney & Singapore & Copenhagen & Geneva & London & Stockholm & Barcelona, \\
\hline Copenhagen & Mexico City & Berlin West & Singapore & Washington & Sydney & Berlin & Seoul & Seoul & Berlin, \\
\hline The Hague & West Berlin & Dublin & Washington & Barcelona & Washington & Sydney & Copenhagen & Barcelona & Geneva s \\
\hline
\end{tabular}

Figure 1. Top 10 Cities for International Congresses 1954-2011 (Source: UIA, 2002, 2005, 2009, 2011)

\section{BENEFITS AND RISKS}

Many articles have discussed that the convention and meeting industry has significant impact on local economics. The real economic impact of the convention and meeting industry should be defined as the "new money" that resulted from the conventions and meetings activities attribute to the society, firms, associations, employment, as well as in-house conference facilities (Dwyer, 1997). However, Ash Morgan (2006) mentioned that when measuring the economic effects of convention and meeting industry, it is important to differentiate the benefits of the construction phase from the operation phase. Benefits received from the construction phase are large but more like a one-time contribution to the local economy; on the contrary, that from the operation phase is small but persistent. Ignored crowding out effect is another factor that may cause inaccurate economic impact evaluation (Mathson, 2002). If a certain destination were already popular when a convention or meeting is on, the hotel and restaurant facilities are already meet or near their capacity, then the visitors' expenditures on the host location are hard to measure.

Not only will the convention and meeting industry generate huge economic benefits to the host city, it also brings large potential non-economic impacts to the destination. Condliffe, S., Jacobson, E., \& Ratledge, E. (2001) explained how a basketball tournament would benefit the local economy on the non-economic side. The events can help the regional or sub-regional government establish its destination image in a good way, which will attract more normal tourists to visit the area after attending events. Also, events will help the government increase its publication on the media or the Internet, which bring more sponsorship in return. Additionally, these events will help the destination build reputation in the industry; hence it will attract more associations to hold same theme conventions, meetings or events.

Despite the value (both tangible and intangible) created by the convention and meeting industry to the local destination, there are also many negative impacts on the destination. As the convention and meeting industry brings a lot of tourists to destination than usual or even more than the its capacity, therefore it would certainly influence the residents' quality of life, environmental well-being and culture protection during these events were holding(Sdrali D. et al., 2015). Also, the overload transportation will cause dissatisfaction among the local natives about the terrible traffic and air pollution. Kyungmi Kim et al., (2012) suggested that the tourism impact on community residents' well-being may vary significantly across different function stage of the community in the tourism development life cycle. When a community enters the decline stage of tourism development, the relationship between the tourism impact and satisfaction of local people are negative.

\section{SITE SELECTION}

In the view of above-mentioned facts, especially the value creating function of conventions and meetings industry played in the community; governments and managers are trying to promote convention and meeting industry to boom the local development. However, not all the communities or the destinations are capable to development the convention and meeting industry. 
According to the study of Crouch and Ritchie (2000), to become a suitable place to hold conventions or meetings, the destination should at least meet the following group of criteria: accessibility, local support, extra-conference opportunities, and accommodation facilities, meeting facilities, information, site environment and other criteria. For example, if the destination is relatively small in size and far in distance, it may not appropriate to promote the convention and meeting industry as large amount investment of infrastructure and facility, such as convention center and convenient transportation facility should be expand at the first stage. If the destination cannot attract enough delegates to the area, they won't be able to receive enough revenue to cover the initial investment, and will greatly increase the financial burden. In the view of the meeting planners or the association managers, the final decision of the site selection is usually made by the CEO or the top managers of the associations. They would like to select a destination that has a good reputation in certain area and well known with local celebrities. It can attract both attendees and business opportunities, and will minimize the possibility of convention failure.

Further studies have paid attention to the determinant factors which will significantly influence the final call of decision making. Yoo and Zhao (2010) suggest that "networking" and "travelability" factors have great impact on the convention participation intention. Previous studies showed that professional and resourceful social networking is a crucial part of attendees' convention experience. Especially during the economic downturn, convention delegates are eager to encounter meaningful social network, which will provide them with career opportunities, information and resources. Positive relationship was also confirmed in the study between the travelability factor and the convention participant intention. In their study, "travelability" was defined as the combination factors, such as distance to travel, personal financial situation, cost and time, and travel funding availability. Because today's attendees are confronted with severe economic recessions resulted in limited convention and travel budget. That will make it more difficult for the participants to choose the conventions or meetings to go. Additionally, the tight schedule of delegates reduces the possibility of spending more free time in the host location as part of the convention experience. This finding can be tested and verified by today's trend of avoiding luxury and foreign locations in selecting a convention or meeting site. This, in turn, showed that the accessibility of the host destination would largely influence the convention participant intentions. Lastly, blindly development of convention and meeting industry without carefully estimated the location's capability would bring negative effect to the host destination.

\section{CONCLUSIONS}

Convention and meeting industry is one of the core drives of tourist destinations. It played vital in the destination development in both economic and social life; and it showed a great potential in the international market. Based on the previous study, we can see that the convention and meeting industry can generate a great deal of income and employment. It can also help the tour destination establish and promote destination image, generate more normal visitors and future investment. However, there are also negatives effects on the residents' quality of life and environment well being derived from the convention industry. Given the great potential and value-creating function, the destinations that can fulfill the criteria of site selection should pay more attention to promote the convention and meeting industry actively

\section{REFERENCES}

[1] Anonymous., It's getting better all the time. MPI business Barometer Annual, 2012, 2-4

[2] Union of International Association, (2012).International meetings statistics for the year 2011. Location: Brussels: UIA.

[3] International Congress and Convention Association, (2012). International Association Meeting Market Statistics Report 20022011. Location: New York: ICCA.

[4] Lew, A. A., \& Chang, T. C., Where the world meets: regionalism and globalization in Singapore's convention industry[J]. Journal of Convention \& Exhibition Management, 1994:4: 17-36.

[5] Dwyer, L., Economic contribution of convention tourism: Conceptual and empirical issues. In K. Weber, \& K. Chon (Eds.), Convention tourism:International research and industry perspectives.2002, (pp. 21-35). New York: Haworth..

[6] Weber,K. \& Chong, K.S., Convention tourism: international research and industry perspectives. New York: Haworth,2002.

[7] Yoo,J.J., \&Zhao, X.,. Revisiting determinants of Convention Participation Decision Making. Journal of Travel and Tourism Marketing. 2010, 27(2), 179-192.

[8] Sangpikul A. and Kim S. S., 2009, An Overview and Identification of Barriers Affecting the Meeting and Convention Industry in Thailand[J], Journal of Convention \& Event Tourism,2009,10: Issue 3, 2009 185-210

[9] Richard, D.A. (2009, September). Why face-to-face business meetings matters, Retrieved March, 2013, from The Hilton Family, http://news.hilton.com.cn/index.cfm/newsroom/detail/147?tl=en,en

[10] Mceuen,M.B. \& Duffy, C., The future of meetings: the case for face-to-face, The Center for Hospitality Research,2010

[11] Morgan, A.,\&Condliffe, S., Measuring the Economic Impacts of Convention Centers and Event Tourism: A Discussion of the Key Issues.Journal of Convention \& Event Tourism.2006, 8 (4): 81-100

[12] Donna, M.A.(2011). Helms Briscoe and Variarts Bring Meetings Procurement TO China. Retrieved March, 2013, from incentive website.http://www.incentivemag.com/News/Industry/Articles/Hel msBriscoe-and-VariArts-Bring-Meetings-Procurement-to-China/

[13] Matheson,V. A., Upon further review: an examination of sporting event economic impact studies. The Sport Journal, 2002, 5(1), 1-6

[14] Condliffe, S., Jacobson, E., \&Ratledge, E. (2001).Economic impact study of the "Slam Dunk To The Beach" Basketball tournament. Retrieved March 2013, from the Center for Applied Demography and Survey Research, University of Delaware Website.http://dspace.udel.edu:8080/dspace/bitstream/handle/1971 6/748/SD_Proper14.pdf;jsessionid=7CAAAAD162CBD850A5350 68E3758C65C?sequence =

[15] Kim, Kyungmi. (2012). How does tourism in a community impact the quality of life of community residents? Tourism management. 2(61),51-77.

[16] Ritchie, J.R.B. \& Crouch. G.I., The Competitive Destination: A Sustainable Tourism Perspective, 2002,21(1):1-7. 